Ady Muzwardi | Kerjasama Korea Selatan-Indonesia dalam Manjemen Bencana Alam (Rekontruksi Aceh Pasca Tsunami Samudera Hidia)

\title{
Kerjasama Korea Selatan -Indonesia dalam Manajemen Bencana Alam (Rekontruksi Aceh Pasca Tsunami Samudera Hindia)
}

\author{
Ady Muzwardi* \\ ady.muz16@gmail.com
}

\begin{abstract}
Natural Distasters is a part of media diplomacy and cooperation between nations, strengthening disaster preparedness for effective response at all levels. In coping with disasters, national resources could be overwhelmed, especially in the event of large-scale disasters. In this respect, bilateral and regional cooperation is of particular importance, and this is part of the Korean Indonesian relations. The political dialogue also intends to foster closer cooperation on humanitarian and activities between the Indonesia and Korean.

The tsunami in Aceh serves as an example of media diplomacy between the two nations as part of global cooperation. The development of political, social and culture cooperation through reconstruction efforts, programs and projects in Aceh has become a strength in the diplomatic relations between South Korea and Indonesia. This research aims to share knowledge and exchange best practices and to be able to work together in the event of major disasters.
\end{abstract}

Keywords:Natural Disasters, diplomacy, reconstruction.

*FISIP, Universitas Maritim Raja Ali Haji

Andalas Journal of International Studies | Vol 5 No 2 November Tahun $2016 \mid 178$ 
Ady Muzwardi | Kerjasama Korea Selatan-Indonesia dalam Manjemen Bencana Alam (Rekontruksi Aceh Pasca Tsunami Samudera Hidia)

\section{A. Latar Belakang}

Secara Sejak tahun 1600 sampai dengan tahun 2007, Indonesia telah mengalami 184 tsunami besar. Apabila kita melihat sumber penyebab terjadinya tsunami tersebut, hampir 90\% kejadiannya disebabkan oleh gempa bumi di laut, 9\% diakibatkan oleh letusan gunung api dan $1 \%$ karena tanah longsor bawah laut. ${ }^{1}$

Tsunami terbesar di Indonesia terjadi pada 26 Desember 2004 dan menjadi salah satu tsunami terbesar di muka bumi.Tsunami tersebut menghantam pantai barat Sumatra dan menyebabkan korban jiwa lebih dari 227,000 serta menghancurkan berbagai fasilitas dan tempat tinggal.Lebih dari 14 negara di sepanjang Samudera Hindia terkena dampak tsunami tersebut.Secara cepat, setelah terjadi tsunami, operasi bantuan yang tidak terduga dimulai.Bantuan tersebut mengalir melalui melalui ratusan negara dan lembaga bantuan internasional dari 130 negara yang berkontribusi terhadap program bantuan darurat yang massive. ${ }^{2}$ Secara cepat operasi bantuan tersebut berjalan untuk pembangunan kembali infrastruktur di Aceh. Di bulan April 2005 pemerintah Indonesia

\footnotetext{
1 Latief, Hamzah, DKK.2000. Tsumani Catalog and Zones in Indonesia.Vol 22. Tohoku University

${ }^{2}$ UNEP.2007 'Environment and Reconstruction in Aceh: Two years after the tsunami'. United Nations Environment Programme publication
}

mengeluarkan sebuah 'Master Plan' untuk mengarahkan rehabilitasi dan rekontruksi kembali Aceh dan disaat bersamaan Presiden Indonesia membentuk Badan Rehabilitasi dan Rekonstruksi (BRR), yang bertugas untuk mengkoordinasikan rehabilitasi dan rekontruksi kembali Aceh.

\section{B. Permasalahan}

Berdasarkanlatarbelakang masalah diatas, maka yang menjadi permasalahan dalam penelitian ini yaitu bagaimana Kerjasama Korea Selatan-Indonesia Dalam Manajemen Bencana Alam dalam Rekonstruksi Aceh Pasca Tsunami Samudera Hindia.

\section{Tujuan}

Adapun tujuan penelitian ini adalah untuk mengetahui bagaimana Kerjasama Korea Selatan-Indonesia Dalam Manajemen Bencana Alam dalam Rekonstruksi Aceh Pasca Tsunami Samudera Hindia.

\section{Metode Penelitian.}

1. Jenis penelitian

Penelitian ini mengunakan jenis penelitian kualitatif yaitu menganalisa permasalahan dari sudut pandang atau bahan pustaka .desain penelitian ini lebih menititiberatkan pada data 
Ady Muzwardi | Kerjasama Korea Selatan-Indonesia dalam Manjemen Bencana Alam (Rekontruksi Aceh Pasca Tsunami Samudera Hidia)

sekunder.Jenis data yang

digunakan dalam penelitian yaitu sekunder.Data sekunder adalah data yang diperoleh dari bahan kepustakaan guna mendapatkan landasan teoritis.

\section{E. Kerangka Teori}

1. Diplomasi Bencana

Diplomasi Bencana menggabungkan dua kata kunci.Berdasarkan kamus Oxford, definisi bencana adalah "suatu kejadian kecelakaan atau penderitaan yang disebabkan oleh perubahan alam yang berdampak kerusakan besar atau berdampak pada hilangnya nyawa manusia" (oxforddictionaries.com).Kata kedua adalah "diplomasi", kata diplomasi memiliki definisi yang berlawanan dengan perang, diplomasi bagian dari negosiasi dengan sisi politik yang kuat.Saat kedua kata tersebut digabung menjadi jawaban dari pertanyaan terkait keterlibatan atau kehadiran dari aktor internasional dalam konflik/bencana. ${ }^{3}$

Semua Diplomasi Bencana membuktikan sejauh ini hubungan

3 Jonsson, C. and Aggestam, K. 2009. "Diplomacy and Conflict Resolution." The SAGE Handbook of Conflict Resolution, eds. Bercovitch, J., Kartman, W. I., and Kremenyuk, V. Hal. 33-51 aktivitas dalam bencana yang dapat menjadi katalis dari diplomasi.Hubungnan yang terjadi antar aktor dalam keadaan bencana dapat menciptakan diplomasi. Dalam jangka pendek (1 minggu atau 1 bulan) dampak diplomasi yang terkait aktivitas penanggulangan bencana dapat berakibat terciptanya hubungan positif.Diplomasi, pembentukan lembaga rekonsiliasi merupakan bagian dari diplomasi baik negosiasi formal. ${ }^{4}$

Menurut Louise K. Comfort, isu bencana sekarang ini menjadi isu yang sangat krusial bagi peningkatan kualitas kesejahteraan manusia.Bencana harus didefinisikan secara lebih luas, tidak hanya sebatas isu bencana alam semata, namun juga bencana penyakit ataupun isu pemanasan global. Pendifinisian bencana sebagai isu global diharapkan akan meningkatkan empati dari masyarakat dunia untuk terlibat bersama menyelesaikan problem bencana.

Disaster Diplomacy examines the role of disaster-related

${ }^{4}$ Kelman, I. 2007. "Disaster diplomacy: Can tragedy help build bridges among countries?" UCAR Quarterly, Fall 2007, p. 6. 
Ady Muzwardi | Kerjasama Korea Selatan-Indonesia dalam Manjemen Bencana Alam (Rekontruksi Aceh Pasca Tsunami Samudera Hidia)

activities not just in
international affairs and
international relations, but
also in political conflict not
involving more than
independent state. Disaster
Diplomacy also embraces a
wide definition of "disaster",
not just rapid-onset events
such as earthquakes and
industrial explosions, but also
events which are more diffuse
in space and time such as
droughts, epidemics, and
global changes. These latter
events have been termed
"chronic disaster", "creeping
changes", and aster
conditions" amongst other
terms"5

Studi kontemporer yang dilakukan oleh I. Kelman menunjukan bahwa bencana tidak selalu menjadi faktor yang buruk bagi masyarakat, namun dalam batas tertentu dapat dikelola untuk menyelesaikan persoalan-persoalan politik dan konflik yang selama ini tak terpecahkan, baik dalam konteks persoalan dalam level nasional

${ }^{5}$ Ilan Kelman.2002.'Disaster Diplomacy How Disasters Affect Peace and Conflict".Routledge.2011.p.15 maupun antara Negara. Argumen besar dari Kelman adalah bencana justru memberikan ruang yang besar bagi pihak-pihakyang memiliki potensi sebagai daerah yang rawan bencana untuk mencari ruang yang bisa dikerjakan untuk mengurangi resiko yang ditimbulkan dari bencana alam itu sendiri.

Studi Kelman tentang semakin menunjukan fungsionalitas diplomasi bencana alam.Dalam studinya juga menunjukan bahwa bencana alam juga dapat dikelola untuk menjadi ruang bagi peningkatan kerjasama politik, ekonomi, sosial budaya yang lebih luas.Negara-negara yang tergolong sebagai daerah yang rawan bencana atau potensial mengalami bencana alam, yang sebelumnya tidak melakukan kerjasama yang intensif, bahkan cenderung bermusuhan secara politik, kemudian memilih melakukan kerjasama untuk mengurangi resiko dan dampak bencana. ${ }^{6}$

\section{Rekonstruksi}

\footnotetext{
6 Surwandono, Herningtyas.2013. "Peningkatan Kapasitas Birokrasi Pemerintah Daerah Propinsi DIY dalam Melakukan Diplomasi Bencana Alam”.FISIPOL UMY. Hal 8
} 
Ady Muzwardi | Kerjasama Korea Selatan-Indonesia dalam Manjemen Bencana Alam (Rekontruksi Aceh Pasca Tsunami Samudera Hidia)

Rekonstruksi menurut Kamus Besar

Bahasa Indonesia (KBBI) adalah pengembalian seperti semula. Secara khusus arti rekonstruksi dalam Penanggulangan bencana dan mitigasi Menurut KBBI ekonstruksi (reconstruction): Adalah program jangka menengah dan yang jangka panjang meliputi perbaikan fisik, sosial dan ekonomi untuk mengembalikan kehidupan masyarakat pada kondisi yang sama atau lebih baik dari sebelumnya. $\|$ rekonstruksi : Pembangunan kembali semua prasarana dan sarana, kelembagaan pada wilayah pascabencana, baik pada tingkat pemerintahan maupun masyarakat dengan sasaran utama tumbuh dan berkembangnya kegiatan perekonomian, sosial dan budaya, tegaknya hukum dan ketertiban, dan bangkitnya peran serta masyarakat dalam segala aspek kehidupan bermasyarakat pada wilayah pascabencana. || rekonstruksi : Rekonstruksi adalah tahap pembangunan kembali semua sarana dan prasarana agar kembali berkembangnya kegiatan perekonomian, sosial budaya, dan bangkitnya peran masyarakat dalam semua aspek kehidupan. B.N Marbun Rekonstruksi adalah pengembalian sesuatu ketempatnya yang semula; Penyusunan atau penggambaran kembali dari bahanbahan yang ada dan disusun kembali sebagaimana adanya atau kejadian semula.Kebutuhan rehabilitasi dan rekonstruksi diperkirakan berdasarkan penilaian kerusakan dan kerugian yang dilengkapi dengan penilaian kebutuhan pemulihan kemanusiaan masyarakat korban bencana untuk memperoleh perkiraan kebutuhan pemulihan pasca bencana.Keterkaitan antara penilaian kerusakan dan kerugian dengan penilaian kebutuhan pemulihan kemanusiaan memberikan umpan balik bagi kebutuhan pemulihan dengan menempatkan masyarakat korban bencana dan lingkungannya sebagai sasaran pemulihan pasca bencana.

Tabel 1. Rekonstruksi Pasca Bencana

\begin{tabular}{|c|c|}
\hline $\begin{array}{l}\text { Disaster assessment } \\
\text { - Rapid assessment } \\
\text { - Preliminary damage assessment } \\
\text { - Site assessment } \\
\text { Short-term recovery } \\
\text { - Impact area security } \\
\text { - Temporary shelterhousing } \\
\text { - Infrastructure restoration } \\
\text { - Debris management } \\
\text { Long-term reconstruction } \\
\text { - Hazard source control and area } \\
\text { protection } \\
\text { - Land-use practices } \\
\text { - Building construction practices } \\
\text { - Public healthimental bealth } \\
\text { rocovery } \\
\text { Recovery management } \\
\text { - A gency notification and } \\
\text { mobilization } \\
\text { - Mobilization of recovery facilities } \\
\text { and equipment } \\
\text { Intemal diroction and control } \\
\text { External coordination } \\
\text { - Public information }\end{array}$ & $\begin{array}{l}\text { - Emergency demolition } \\
\text { - Repair pemitting } \\
\text { - Donations management } \\
\text { - Disas ter assistance } \\
\text { - Economic development } \\
\text { - Infrastructure resilienoe } \\
\text { - Historic preservation } \\
\text { - Environmental recovery } \\
\text { - Disaster memorialization }\end{array}$ \\
\hline
\end{tabular}

Andalas Journal of International Studies | Vol 5 No 2 November Tahun $2016 \mid 182$ 
Ady Muzwardi | Kerjasama Korea Selatan-Indonesia dalam Manjemen Bencana Alam (Rekontruksi Aceh Pasca Tsunami Samudera Hidia)

(Sumber : Lindell. 2013. Recovery

And Reconstruction After

Disaster.Springer. Texas. Hal 815)

Rekonstrusi pasca bencana memerlukan dana yang besar sehingga negara-negara yang mengalami bencana alam yang besar memerlukan kerjasama dengan negara-negara donor. Fase rekonstruksi pasca bencana dimulai dari proses penilaia kebutuhan dilapangan (assessment) fungsi assessment sangat penting dalam rekonstruksi pasca bencana, melalui assessment dampak darurat pasca bencana dapat diidentifikasi terutama untuk membangun kembali rumah korban dan fasilitas umum lainya.

Pembangunan kembali memerlukan pembuatan program yang dirancang dari kerjasama negara donor dengan negara yang mengalami bencana.Konsep rekonstruksi pada umumnya dimulai dari perencanaan sektor yang memiliki kebutuhan paling mendasar sehingga pembuatan program rekonstruksi dibantu dengan kemudahaan dari regulasi yang ada dan pelaporan keuangan yang transparan dan memiliki akuntabilitas. Untuk tenaga ahli dalam rekonstruksi banyak mengambil dari negara donor sebagai bagian dari kerjasama yang bukan hanya memberikan bantuan dana tetapi juga tenaga ahli.

Gambar1. Proses Penilaian Kebutuhan Pasca bencana danPenyusunan Rencana Aksi

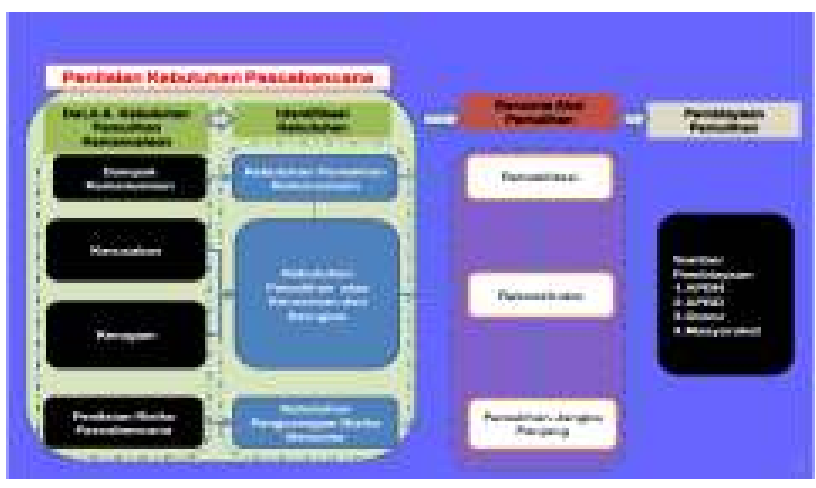

Sumber: BNPB.2014.Rencana aksi rehabilitasi dan rekonstruksi wilayahpasca bencana gempa bumi kabupaten aceh tengah dan bener meriah tahun 2013 - 2014. Hal 62

F. HASIL DAN PEMBAHASAN

1. Hubungan Diplomatik Korea Selatan dan Indonesia

Indonesia dan Korea Selatan telah menunjukkan hubungan yang erat sejak pembentukan hubungan diplomatik pada tahun 1973. Hubungan baik yang terjalin, salah satunya dibuktikan pada tahun 2012 , sekitar 300.000 warga negara Korea 
Ady Muzwardi | Kerjasama Korea Selatan-Indonesia dalam Manjemen Bencana Alam (Rekontruksi Aceh Pasca Tsunami Samudera Hidia)

Selatan mengunjungi Indonesia dan 149.000 warga negara Indonesia mengunjungi Korea Selatan. ${ }^{7}$

Hubungan kenegaraan antara Indonesia dan Korsel telah berjalan sejak keduanegara tersebut menandatangani persetujuan pembukaan hubungan diplomatik kenegaraan tingkat konsuler pada 1966. Sebagai langkah pertama dimulainya hubungan kenegaraan resmi antara Indonesia-Korea Selatan tingkat konsuler tersebut, adalah dengan dibukanya banyak kesempatan bagi kedua negara untuk bekerja sama di berbagai bidang demi tercapainya kepentingan kedua negara.

Total perdagangan Indonesia dengan Korea Selatan pada periode Januari-Februari 2013 sebesar US\$4.415,38 juta, turun $16,64 \%$ dibanding periode Januari-Februari 2012, yang tercatat US\$5.296,89 juta. Total perdagangan periode Januari-Februari 2012 tersebut, terdiri dari ekspor Indonesia ke Korea Selatan sebesar US\$2.188,82 juta yang turun $25,21 \%$ dibanding periode yang sama tahun 2012 yang mencapai US\$2.926,45 juta, dan

${ }^{7}$ http://ipsk.lipi.go.id/berita/208-indonesia-koreaselatan-semakin-mantapkan-hubungan-diplomatik. diakses 16 Oktober 2016 impor Indonesia dari Korea Selatan sebesar US\$2.226,56 juta juga turun $6,07 \%$ dibanding periode yang sama tahun 2012, yang tercatat sebesar US\$2.370,44 juta. Neraca perdagangan Indonesia dengan Korea Selatan defisit bagi Indonesia sebesar US\$37,73 juta. Sementara itu, pada periode yang sama tahun 2012, Indonesia berhasil mencatatkan surplus sebesar US\$556,01 juta.

Pada periode Januari - Februari 2013 produk ekspor non-migas utama Indonesia ke Korea Selatan adalah barang-barang tambang (batubara, nikel, tembaga, dll), karet alam, bahan kimia, produk kayu, benang, dan peralatan listrik rumah tangga. Penurunan permintaan beberapa barang tambang Indonesia dari Korea Selatan disebabkan pengalihan impornya ke negaranegara lainnya seperti Australia, Jepang, dan Amerika Serikat.

Hubungan bilateral IndonesiaKorea Selatan terus mengalami perkembangan dan peningkatan yang cukup signifikan di berbagai bidang dari tahun ke tahun.Hubungan yang erat ini terlihat dengan adanya peningkatan kerjasama yang pesat yang tercermin dari semakin bertambahnya ikatan kerjasama 
Ady Muzwardi | Kerjasama Korea Selatan-Indonesia dalam Manjemen Bencana Alam (Rekontruksi Aceh Pasca Tsunami Samudera Hidia)

antara kedua negara di berbagai bidang yang mencakup politik, pertahanan dan keamanan, ekonomi, perdagangan dan sosial budaya.

Indonesia dan Republik Korea mendirikan hubungan diplomatik pada tanggal 17 September 1973.Kemitraan strategis kedua negara mulai dijalin sejak 4 Desember 2006.Kerjasama kedua negara mengalami kemajuan yang signifikan dalam beberapa tahun terakhir sebagai hasil dari summit diplomacy, konsultasi, dan komunikasi pada tataran working level serta pertukaran antarmasyarakat yang intensif.

Republik Korea saat ini tercatat sebagai mitra dagang terbesar keempat dan investor asing terbesar ketiga Indonesia. Pada tahun 2012, volume perdagangan kedua negara adalah sebesar US\$27,02 milyar. Sementara investasi Republik Korea di Indonesia mencapai USD1,94 milyar, atau naik lebih dari 55\% dari tahun sebelumnya.

Bentuk diplomasi Korea Selatan melalui diplomasi publik, yang bertujuan untuk menjadi negara yang paling dicintai di dunia. Upaya diplomasi Korea Selatan, dipelopori dengan cara mempromosikan TV drama Korea dan music K-pop global, namun negara ini juga meluncurkan berbagai macam proyek-proyek publik diplomasi atas dasarpendanaan pemerintah termasuk proyek penanganan bencana alam, dimana untuk tahun fiscal 2014di bawah pemerintahan Geun-hye nilainya sekitar 50\% lebih tinggi dari tahun sebelumnya, pada 9miliar won (sekitar $¥ 870.000 .000$ ). ${ }^{8}$ Dengan ekonomi yang terus berkembang dalam beberapa dekade terakhir, Korea Selatan menjadi salah satu "Macan Asia" dengan menjadi pemain terkemuka di kawasan Asia.Dengan hubungan bisnis dan perdagangan di seluruh dunia, Korea Selatan berjuang untuk menjadi salah satu pusat ekonomi Asia yang lebih terpadu bekerjasama dengan Indonesia. Fokus kerjasama Korea Selatan lebih menekankan pada pada strategi promosi yang bersifat diplomatik dengan fokus yang lebih global. Korea Selatan memiliki lima tujuan menuju diplomasi global yang berorientasi masa depan yaitu:

${ }^{8}$ Kwong Yongseok 2014 annual report - Korea Foundation 
Ady Muzwardi | Kerjasama Korea Selatan-Indonesia dalam Manjemen Bencana Alam (Rekontruksi Aceh Pasca Tsunami Samudera Hidia)

1. Konsolidasi hubungan diplomatik Korea dengan negara-negara tetangganya.

2. Memperluas upaya diplomatik Korea di wilayah lain.

3. Konsolidasi upaya diplomatik multilateral Korea.

4. Dukungan untuk pengembangan masyarakat Korea di luar negeri.

5. Mengejar aktif diplomasi budaya.

Fokus-fokus kerjasama Korea Selatan menjadi peluang kerjasama diantara Indonesia dan Korea Selatan terutama sebagai bentuk konsolidasi hubungan Korea Selatan dan Indonesia.

Tabel 1 Bantuan Korea (ODA) ke Indonesia: 2006-2010

\begin{tabular}{|l|l|l|l|l|l|l|}
\hline Year & $\begin{array}{l}200 \\
6\end{array}$ & $\begin{array}{l}200 \\
7\end{array}$ & $\begin{array}{l}200 \\
8\end{array}$ & 9 & $\begin{array}{l}201 \\
0\end{array}$ & $\begin{array}{l}\text { Tot } \\
\text { al }\end{array}$ \\
\hline $\begin{array}{l}\text { Loa } \\
\text { ns }\end{array}$ & $\begin{array}{l}53 . \\
0\end{array}$ & - & 58. & 58. & 140 & 309 \\
\hline $\begin{array}{l}\text { Gran } \\
\text { ts }\end{array}$ & $\begin{array}{l}24 . \\
0\end{array}$ & 24. & 21. & 16. & 18. & 104 \\
\hline $\begin{array}{l}\text { Tota } \\
1\end{array}$ & 70. & 24. & 80. & 74. & 158 & 414 \\
\hline
\end{tabular}

Sumber: https://data.oecd.org/korea.htm. diakses 16 Oktober 2016
Indonesia-Korea

Comprehensive

Economic

Partnership Agreement (IK-CEPA) yang telah memasuki negosiasi putaran ketiga diharapkan dapat mendorong pencapaian target perdagangan bilateral sebesar USD50 milyar pada tahun 2015 dan USD100 milyar tahun 2020. Dalam kaitan ini, IK-CEPA merupakan kerangka dan modalitas kerja sama saling menguntungkan di bidang ekonomi secara komprehensif dan tidak hanya di sektor perdagangan.

Selain isu bilateral, kedua Menteri Luar Negeri juga bertukar pandang mengenai situasi strategis di kawasan, khususnya terkait Semenanjung Korea. Kedua Menlu juga sepakat untuk mempererat kerja sama di forum regional dan internasional, antara lain dalam kerangka ASEAN-ROK, ASEAN Plus Three, ARF, EAS, FEALAC, dan APEC. 9

\section{Strategi Partnership Korea- Indonesia dalamRekonstruksi Aceh}


Ady Muzwardi | Kerjasama Korea Selatan-Indonesia dalam Manjemen Bencana Alam (Rekontruksi Aceh Pasca Tsunami Samudera Hidia)

Strategi partnership bertujuan untuk mendukung pengurangan kemiskinan dan pembangunan berkelanjutan di Indonesia yang sesuai dengan Rencana Pembangunan Jangka Panjang dan Menengah Nasional 2005-2005 (RPJMN) dan Master Plan untukAkselerasi dan Ekspansi Pembangunan Ekonomi Indonesia (MP3EI).Master Plan tersebut menjadi tampilan dari kerangka kerja dalam penguatan hubungan bilateral Korea dan Indonesia melalui Deklarasi Kerjasama dalam strategi Partnership sebagai media untuk mempromosikan persahabatan dan kerjasama di abad yang ditandatangani tanggal 4 Desember 2006 oleh kedua pimpinan negara. Implementasi dari deklarasi tersebut melalui pembentukan komite bersama dalam kerjasama ekonomi dan pembentukan Working Level Task Force. ${ }^{10}$

Kerjasama pembangunan Korea untuk Indonesia (2006-2010) secara total diperkirakan US\$414.2 juta (US\$309.9 juta dalam bentuk dana

\footnotetext{
${ }^{10}$ Republic of Korea.2012.Country Partnership Strategy for the Republic of Indonesia 20122015.
} konsesi dan US\$104.3 juta dalam bentuk komitmen anggaran) yang telah dialokasikan untuk Indonesia dalam periode 2006 sampai 2010 (rata-rata dengan dana rutin US\$83 juta).total bantuan dana Korea (ODA) untuk Indonesia dalam 2006 (US\$77.0 juta), dan sebagian besar dana untuk rekonstruksi Aceh, hal ini sebagai cemin kerjasama pembangunan kedua negara.

Kerjasama pemerintah Indonesia dengan pemerintah Korea Selatan dalam bidang disaster management lebih menekankan pada pencegahan dan penanggulangan bencana. Salah satunya kerjasamanya adalah pembangunan Tsunami Response di wilayah-wilayah rawan bencana tsunami.

Untuk mengatur kerjasama dalam tsnunami response, Pemerintah Korea Selatan membentuk satuan gugus tugas yang memiliki respon yang cepat untuk mengatur kegiatan bantuan secara sistematis dengan bekerja sama dengan sektor swasta seperti ketika terjadinya bencana Tsunami Samudera Hindia.

Pemerintah Korea Selatan telah merespon secara cepat ketika Tsunami Samudera Hindia terjadi 
Ady Muzwardi | Kerjasama Korea Selatan-Indonesia dalam Manjemen Bencana Alam (Rekontruksi Aceh Pasca Tsunami Samudera Hidia)

dengan memberikan bantuan sebesar $\$ 50$ juta, bantuan tersebut merupakan bantuan terbesar Korea Selatan terhadap bencana di luar Korea Selatan. Dari total jumlah tersebut, USD5 juta dialokasikan untuk bantuan darurat, dan $\$ 45$ juta untuk rekonstruksi. Indonesia menerima bagian terbesar (\$17.200.000) dari bantuan Korea Selatan karena menjadi negara yang paling parah terkena dampak bencana tsunami.Pemerintah Korea Selatan telah melaksanakan delapan proyek manajemen bencana alam di Indonesia termasuk melakukan rekonstruksi pembangunan sekolah dan rumah sakit.The Korea International Cooperation Agency (KOICA) berperan aktif dalam pengiriman kelompok relawan, dengan mengirim 73 relawan dalam tiga tahap.Para relawan yang terlibat berbagai kegiatan pemulihan bencana, bantuan tenaga kesehatan dan perawatan medis dan field staff assistance.

Tabel 1. KOICA's Response to the Indonesian Tsunami 2004

\begin{tabular}{|l|l|l|}
\hline Phase & $\begin{array}{l}\text { Volum } \\
e\end{array}$ & Activities \\
\hline Emer & $\$ 1.3 m$ & $-\$ 0.6 M$ in financial \\
\hline
\end{tabular}

\begin{tabular}{|c|c|c|}
\hline $\begin{array}{l}\text { gency } \\
\text { Relief }\end{array}$ & illion & $\begin{array}{l}\text { aid } \\
\text { - \$0.7M in supplies } \\
\text { including medicine, } \\
\text { tents, blanket and } \\
\text { water tanks } \\
\text { - Emergency relief } \\
\text { volunteers } \\
\text { primary to } \\
\text { shelters in Banda } \\
\text { Aceh }\end{array}$ \\
\hline $\begin{array}{l}\text { Recov } \\
\text { ery } \\
\text { and } \\
\text { Recon } \\
\text { structi } \\
\text { on }\end{array}$ & $\begin{array}{l}\$ 15.9 \\
\text { millio } \\
n\end{array}$ & 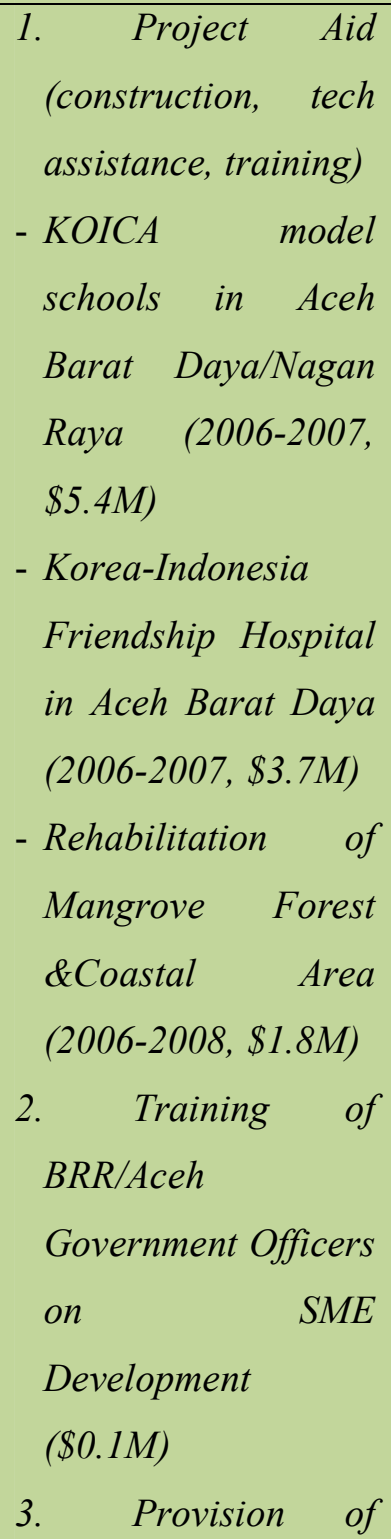 \\
\hline
\end{tabular}


Ady Muzwardi | Kerjasama Korea Selatan-Indonesia dalam Manjemen Bencana Alam (Rekontruksi Aceh Pasca Tsunami Samudera Hidia)

\begin{tabular}{|c|c|c|}
\hline & & $\begin{array}{l}\text { Reconstruction } \\
\text { Equipments/Supplies } \\
\text { - Tents, Blankets, } \\
\text { financial aid for } \\
\text { Recovery of Nias } \\
\text { Island (\$0.2M) } \\
\text { - Relief supplies for } \\
\text { refugees and } \\
\text { provision of } \\
\text { reconstructionequip } \\
\text { ment in Banda Aceh } \\
\text { (\$2 M) } \\
\text { - Repairing } \\
\text { Fishing boats (\$0.8 } \\
\text { M) } \\
\text { - Provision of mobile } \\
\text { cranes } \\
\text { rehabilitate harbors } \\
\text { in Aceh The Project for } \\
\text { Disaster Information } \\
\text { Dissemination } \\
\text { System in Indonesia }\end{array}$ \\
\hline $\begin{array}{l}N G O \\
\text { fundin } \\
g\end{array}$ & $\begin{array}{l}\$ 0.7 \mathrm{~m} \\
\text { illion }\end{array}$ & \\
\hline
\end{tabular}

Sumber: KOICA. 2009."Evaluation of KOICA's Tsunami Response in Indonesia".Hal.17

Kerjasama Indonesia dengan Korea Selatan melalui kerjasama kementerian luar negeri Indonesia dengan Humanitarian Aid Division melalui Ministry of Foreign Affairs and Trade (MOFAT) Korea Selatan, melalui KOICA. Sistem kerjasama yang dilakukan Korea Selatan dan Indonesia melalui MOFAT lebih khusus kepada lintas departemen yang dilibatkan dalam proses rekonstruksi.Humanitarian Aid Division memiliki kerjasama langsung dengan Badan Perencanaan Pembangunan Nasional (BAPENNAS) melalui koordinasi kementerian luar negeri.

Gambar 2.Kerjasama Indonesia-Korea Selatan dalam kerjasama Disaster Management

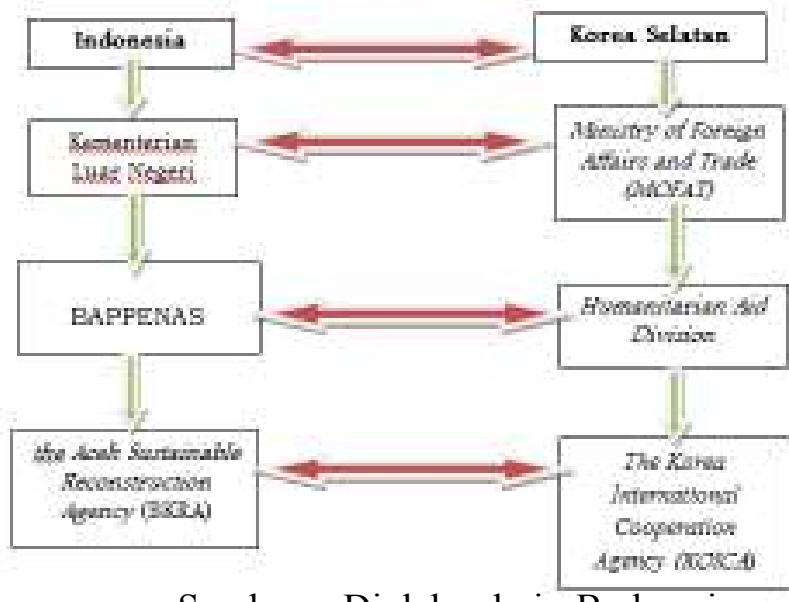

Sumber: Diolah dari Berbagai Sumber

\section{Proyek Rekonstruksi Aceh} Pasca Tsunami

$$
\text { Proyek rekonstruksi }
$$

membutuhkan koordinasi yang kuat 
Ady Muzwardi | Kerjasama Korea Selatan-Indonesia dalam Manjemen Bencana Alam (Rekontruksi Aceh Pasca Tsunami Samudera Hidia)

antar lembaga dari kedua belah negara yaitu Indonesia dan Korea Selatan, karena proyek rekonstruksi adalah proyek yang berkelanjutan.Pemerintah Korea Selatan melalui KOICA melakukan koordinasi dengan pemerintah pusat sampai dengan pemerintahan tingkat lokal di Indonesia.Proyek rekonstruksi Aceh melalui konsultasi antara KOICA dengan BAPPENAS dan BKRA. Beberapa proyek kerjasama Korea Selatan dan Indonesia setelah Tsunami meliputi proyek The Korea-Indonesia Friendship Hospital, dimana proyek tersebut bertujuan untuk (1.)meningkatkanbidang

kesehatandiAceh, (2.) meningkatkan kualitas pelayanan kesehatandiAcehdengan mentransferteknik pelayanan medis yang canggihdan(3.) meningkatkankondisikesehatan secara keseluruhandi wilayah yang terkena dampak tsunami.

Tabel 2.Timeline for KoreaIndonesia Friendship Hospital

\begin{tabular}{|c|c|}
\hline $\begin{array}{l}\text { Jan. } \\
2005\end{array}$ & $\begin{array}{l}\text { Korean Government } \\
\text { committed to pledge total } \\
\$ 50 \text { million of assistance } \\
\text { for2 yrs.('05-'07) at }\end{array}$ \\
\hline
\end{tabular}

\begin{tabular}{|c|c|}
\hline & ASEAN Summit \\
\hline $\begin{array}{l}\text { Jul. } \\
12 \text { th, } \\
2005\end{array}$ & $\begin{array}{l}\text { Reached tentative mutual } \\
\text { agreement on the direction } \\
\text { of reconstruction project } \\
\text { with BRR \& Aceh } \\
\text { Government personnel }\end{array}$ \\
\hline $\begin{array}{l}\text { Sept. } \\
7 \text { th, } \\
2005\end{array}$ & $\begin{array}{l}\text { MOU contract notice and } \\
\text { request for dispatch of } \\
\text { project-related personnel } \\
\text { to Banda Aceh }\end{array}$ \\
\hline $\begin{array}{l}\text { Oct. } \\
10 \text { th, } \\
2005\end{array}$ & Proposal for project area \\
\hline $\begin{array}{l}\text { Nov. } \\
20 \text { th- } \\
27 \text { th, } \\
2005\end{array}$ & $\begin{array}{l}\text { Dispatch of KOICA } \\
\text { assessment team to Aceh } \\
\text { Province }\end{array}$ \\
\hline $\begin{array}{l}\text { Dec. } \\
13 \text { th } \\
2005\end{array}$ & $\begin{array}{l}\text { Established project basic } \\
\text { framework }\end{array}$ \\
\hline $\begin{array}{l}\text { Jan. } \\
11 \text { th, } \\
2006\end{array}$ & $\begin{array}{l}\text { Creation of project } \\
\text { implementation plan }\end{array}$ \\
\hline $\begin{array}{l}\text { Apr. } \\
17 \text { th, } \\
2006\end{array}$ & $\begin{array}{l}\text { Exchange of agreement } \\
\text { from both governments }\end{array}$ \\
\hline $\begin{array}{l}\text { Apr. } \\
30 \text { th, } \\
2008\end{array}$ & $\begin{array}{l}\text { Installation of medical } \\
\text { equipments }\end{array}$ \\
\hline $\begin{array}{l}\text { May. } \\
\text { 22nd, }\end{array}$ & $\begin{array}{l}\text { Held ceremony for building } \\
\text { completion }\end{array}$ \\
\hline
\end{tabular}

Andalas Journal of International Studies | Vol 5 No 2 November Tahun 2016 |190 
Alam (Rekontruksi Aceh Pasca Tsunami Samudera Hidia)

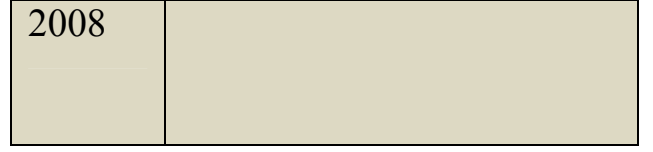

Sumber: Koica, 2009, 33

Selain pembangunan The Korea-Indonesia

Friendship

Hospital, Indonesia dan Korea

Selatan juga melakukan kerjasama pembangunan Aceh Model School di wilaya Naga Raya (1 TK, 1 SD, 1 SMP, 1 SMA), tiga sekolah di Aceh Barat Daya (1 SD, 1 SMP, SMA).

Tabel 3.Timeline for Aceh Model School Project

\begin{tabular}{|c|c|}
\hline $\begin{array}{l}\text { Jan. } \\
2005\end{array}$ & $\begin{array}{l}\text { Korean government makes } \\
\text { commitment for total } \\
\text { assistance of } \$ 50 \text { million for } \\
\text { two years (2005-2007) to } \\
\text { disaster-stricken countries } \\
\text { at ASEAN summit }\end{array}$ \\
\hline $\begin{array}{l}\text { Jul. } \\
12 \text { th, } \\
2005\end{array}$ & $\begin{array}{l}\text { Initial agreement on the } \\
\text { reconstruction project } \\
\text { selection and direction with } \\
\text { BRR and Aceh Government } \\
\text { officials }\end{array}$ \\
\hline $\begin{array}{l}\text { Sept. } \\
7 \text { th, } \\
2005\end{array}$ & $\begin{array}{l}\text { MOU signed and project } \\
\text { correspondence from } \\
\text { headquarter requested. }\end{array}$ \\
\hline $\begin{array}{l}\text { Oct. } \\
10 \text { th, } \\
2005\end{array}$ & Nominates project areas \\
\hline $\begin{array}{l}\text { Jan. } \\
11 \text { th, }\end{array}$ & $\begin{array}{l}\text { Establishment of project } \\
\text { implementation plan }\end{array}$ \\
\hline
\end{tabular}

\begin{tabular}{|c|c|}
\hline 2006 & \\
\hline $\begin{array}{l}\text { Apr. } \\
17 \text { th, } \\
2006\end{array}$ & $\begin{array}{l}\text { Agreements exchanged } \\
\text { between the two } \\
\text { governments }\end{array}$ \\
\hline $\begin{array}{l}\text { Apr. } \\
30 \text { th, } \\
2008\end{array}$ & School supplies installed \\
\hline $\begin{array}{l}\text { May. } \\
\text { 22nd, } \\
2008\end{array}$ & $\begin{array}{l}\text { Building completion } \\
\text { ceremony held }\end{array}$ \\
\hline
\end{tabular}

Sumber: Koica 2009, 42

\section{Kesimpulan}

Keseluruhan paparan di atas memberikan gambaran bagaimana kerjasama Indonesia dengan Korea Selatan dalam penanganan bencana alam.Bencana alam dapat menjadi media kerjasama yang kuat bagi kedua negara sebagai bentuk hubungan transnasional.Pembangunan rumah sakit \& sekolah di Aceh menjadi media diplomasi Korea Selatan untuk menguatkan hubungan kerjasamanya dengan Indonesia.Koordinasi dalam rekonstruksi di Aceh menjadi harmonisasi hubungan diplomatik kedua negara.

Kerjasama yang erat semakin memperkuat persaudaraan kedua negara, melalui proyek rekonstruksi kerjasama Korea Selatan-Indonesia di Aceh menjadi bentuk konsolidasi hubungan diplomatik Korea Selatan dengan negara-negara mitranya. 
Ady Muzwardi | Kerjasama Korea Selatan-Indonesia dalam Manjemen Bencana Alam (Rekontruksi Aceh Pasca Tsunami Samudera Hidia)

\section{DAFTAR PUSTAKA}

\section{Buku-Buku:}

B.N. Marbun, 1996, Kamus Politik, Jakarta. Pustaka Sinar Harapan,

Latief, Hamzah, DKK.2000. Tsumani

Catalog and Zones in Indonesia.Vol

22. Tohoku University

Gaillard, J.-C.Clave, and I. Kelman.

"Wave of Peace? Tsunami disaster

diplomacy in Aceh, Indonesia."

Geoforum, Vol.39, no.1. 2008

Jonsson, C. and Aggestam, K. 2009.

"Diplomacy and Conflict

Resolution." The SAGE Handbook

of Conflict Resolution, eds.

Bercovitch, J., Kartman, W. I., and

Kremenyuk, V. pp. 33-51

Kwong Yongseok 2014 annual report -

Korea Foundation

Republic of Korea.2012.Country

Partnership Strategy for the

Republic of Indonesia 2012-2015.

UNEP.2007 'Environment and

Reconstruction in Aceh: Two years

after the tsunami'. United Nations

Environment Programme publication

\section{Jurnal / Artikel/Penelitian :}

BNPB. 2014. Rencana aksi rehabilitasi dan rekonstruksi wilayah pasca bencana gempa bumi kabupaten aceh tengah dan bener meriah tahun 2013 - 201.4

KOICA.“Evaluation of KOICA's Tsunami Response in Indonesia".

KOICA.2009

Michael K. Lindell. 2013. Recovery

AndReconstruction After

Disaster.Springer. Texas

Surwandono, Herningtyas. "Peningkatan

Kapasitas Birokrasi Pemerintah

Daerah Propinsi DIY dalam

Melakukan Diplomasi Bencana

Alam”.FISIPOL UMY. 2013

Website:

https://www.oxforddictionaries.com/

Tempo,com. 2013. "Indonesia-Korea

Selatan Tingkatkan Hubungan".

Diakses dari

http://www.tempo.co/read/news/201

3/06/13/118488162/Indonesia-

Korea-Selatan-Tingkatkan-

Hubungan diakses pada tanggal $14 \mathrm{O}$

ktober 2016 
Ady Muzwardi | Kerjasama Korea Selatan-Indonesia dalam Manjemen Bencana Alam (Rekontruksi Aceh Pasca Tsunami Samudera Hidia)

http://ipsk.lipi.go.id/berita/208-indonesia-

korea-selatan-semakin-mantapkan-

hubungan-diplomatik diakses pada

tanggal $14 \mathrm{O}$ ktober 2016

Wikia,com. 2013. "South Korea's

Diplomatic Efforts”. Diakses dari

http://publicdiplomacy.wikia.com/wi

ki/South_Korea diakses pada tanggal

14 O ktober 2016

Nippon,com. 2013. "The Age of Public

Diplomacy: Soft Power Game in

East Asia”. Diakses

http://www.nippon.com/en/features/c

00721/diakses pada tanggal $14 \mathrm{O}$

ktober 2016 